\title{
Mayfly ecological traits in a European karst spring: species, microhabitats and life histories
}

\author{
M. Vilenica ${ }^{1,}$ M. Bilić ${ }^{2}$, V. Mičetić Stanković ${ }^{3}$ and M. Kučinić ${ }^{4}$ \\ ${ }^{1}$ University of Zagreb, Faculty of Teacher Education, Trg Matice hrvatske 12, 44250 Petrinja, Croatia. Corresponding \\ author.Email: marina.vilenica@gmail.com \\ ${ }^{2}$ Stenjevečka ulica 8 K, 10000 Zagreb. \\ ${ }^{3}$ Croatian Natural History Museum, Demetrova 1, 10000 Zagreb, Croatia \\ ${ }^{4}$ University of Zagreb, Faculty of Science, Department of Biology, Rooseveltov trg 6, 10000 Zagreb, Croatia
}

Key words: Life cycle, Low species richness, Microhabitats, New species data.

\begin{abstract}
Despite the recent increase in the number of mayfly studies in karst freshwater habitats, their biology and ecology in springs are still poorly characterized. Therefore, we studied mayfly assemblages in a European karst rheocrene spring at five microhabitats monthly over a one-year period. Three species were recorded: Baetis alpinus (Pictet, 1843), Baetis rhodani (Pictet, 1843) and Rhithrogena braaschi (Jacob, 1974). The latter species represents a new record for the fauna of Bosnia and Herzegovina. All three species inhabited all studied microhabitats but with varying abundance. Individual species were associated with a specific substrate type and/or water velocity and/or water depth. The grazer/scraper $R h$. braaschi was most common at microhabitats with inorganic substrate (cobbles, mixture of pebbles and sand), moderate water velocity and higher water depth. The rheophilic grazer/scraper and gatherer/collector B. alpinus was most common at microhabitats with mosses and highest water velocity. The grazer/scraper and gatherer/collector $B$. rhodani was recorded at all microhabitats, yet due to its preference for moderate water velocity, the highest number of individuals were collected from cobbles. We recorded movements of mayfly nymphs among the available microhabitats during their life cycles, due likely to their dietary requirements and search for suitable refugia. Baetis alpinus has a bivoltine, B. rhodani polyvoltine and $R h$. braaschi univoltine life cycle with a long emergence period. The results presented here contribute to the knowledge of spring and mayfly ecology.
\end{abstract}

Abbreviations: HCA-Hierarchical cluster analysis, NMDS-Non-metric multidimensional scaling, UPGMA (Unweighted Pair Group Method with Arithmetic Mean).

Nomenclature: Bauernfeind and Soldán (2012).

\section{Introduction}

Springs are isolated freshwater habitats formed at places where groundwater wells to the land surface. These complex ecotones are characterized by the interaction of groundwater, surface water and terrestrial ecosystems, resulting in stable environmental conditions and high heterogeneity of the aquatic, semi-aquatic and terrestrial microhabitats (e.g., Cantonati and Ortler 1998, Barquín and Scarsbrook 2008, Kløve et al. 2011). Due to thermal constancy, relative hydrological and physicochemical stability of spring systems, many biological processes (e.g., life histories, evolutional processes, microhabitat preferences, behaviour, biogeographical traits) can be studied under naturally controlled conditions. These conditions are also repeatable in the laboratory, making springs natural laboratories (Odum 1957, Likens 2010). Many studies showed that springs harbour a unique and diverse aquatic fauna, and therefore could be considered as important freshwater biodiversity hotspots (Ferrington 1995, Smith et al. 2003, Cantonati et al. 2006, Staudacher and Füreder 2007). Humans have historically benefited from springs, given their considerable cultural significance (Scarsbrook et al. 2007), but even more importantly, they represent a crucial source of drink- ing water. Yet, due to their isolation and small dimensions, spring habitats are particularly sensitive and endangered by numerous anthropogenic activities, such as water abstraction, sedimentation, removal of the surrounding vegetation, nutrient deposition and the effects of climate change (Cantonati et al. 2006). Despite the peculiarity, high ecological value and biological complexity of these habitats, springs have not been sufficiently included in freshwater ecological studies.

This study was conducted in a rheocrene spring located in the largest continuous karst landscape in Europe, the Dinaric Karst, extending over approximately $60,000 \mathrm{~km}^{2}$ (Mihevc et al. 2010). The karst landscape is formed by a complex of morphological, hydrological and hydrogeological terrain features shaped by water soluble rock. Due to the specificity of karst geology and hydrology (e.g., specific physical, chemical, thermal conditions, distinctive water circulation and storage both on the surface and underground), the inhabiting organisms had to adapt to survive in such a challenging environment (Bonacci 2009). Therefore, Dinaric Karst habitats have been recognized as biodiversity hotspots, with high levels of endemism (e.g., Bonacci 2009, Ivković and Plant 2015, Previšić et al. 2014). However, many of these habitats and 
their biota remain insufficiently investigated and a potential and interesting subject of research.

Mayflies are an aquatic insect order widely used as indicators in bio-monitoring assessments (e.g., Lenat and Penrose 1996, Ferro and Sites 2007). They represent a large proportion of the aquatic ecosystems biomass, contributing up to $25 \%$ of total zoobenthos production (Elliott et al. 1988). Due to changes in environmental conditions (i.e., habitat morphology, substrate type, physical and chemical water properties), the composition and structure of mayfly assemblages change downstream in the lotic habitats (e.g., Moog and Hartmann 2017, Vilenica et al. 2016a, b, 2017a, b). The most diverse assemblages are typical for the upper reaches of fast flowing streams and rivers, while springs and high mountain habitats usually have low diversity (Bauernfeind and Soldán 2012). Systematic studies providing detailed data on mayfly ecological traits, such as life cycles, microhabitat, habitat and environmental preferences, are critical for understanding freshwater ecosystem functioning (e.g., Brittain 1991, Raddum and Fjellheim 1993, Erba et al. 2003). Despite the recent increase in research examining mayfly ecology in karst freshwater habitats (Vilenica et al. 2014, 2016ab, 2017ab, Petrović et al. 2015), their assemblages in springs remained poorly characterized (Savić et al. 2016). Therefore, rare, unusual, new and taxonomically interesting findings are expected.

The main goal of this study was to fill the existing knowledge gap concerning the ecological traits of mayflies in Southeast Europe. The research questions asked were: a) What are the composition and structure (longitudinal and trophic) of mayfly assemblages at different microhabitats? b) Which are the preferred microhabitats (i.e., substrate type, water depth and velocity) for the recorded species? c) Do microhabitat preferences change during the life cycle? and d) What are the mayfly life cycles in the investigated karst spring?

\section{Material and methods}

\section{Study area}

The Bistrica River is a typical watercourse in the deep and well-developed Dinaric Karst. The river flows over three $\mathrm{km}$ through Southwestern Bosnia and Herzegovina, through the largest karst field or polje, Livanjsko polje. The rheocrene spring of the river is located in the town of Livno ( $\mathrm{N}$ 4349'55.76”; E 1700'31.21”, altitude $777 \mathrm{~m}$ ) on the slopes of the Bašajkovac hill. The spring is partially encased in concrete, and several houses stand near the spring (see Fig. 1) (Malez 1963, Magdalenić 1971). The climate is transitive from sub-Mediterranean to continental. The mean annual air temperature during the study period was $10.4^{\circ} \mathrm{C}$ (mean minimum $4.2^{\circ} \mathrm{C}$; mean maximum $17.1^{\circ} \mathrm{C}$ ), and the annual rainfall was $1090.7 \mathrm{~mm}$ (FHMZ BIH 2013).

\section{Mayfly sampling}

Mayfly nymphs were collected together with other macroinvertebrates on a monthly basis in the period from September 2007 to August 2008. Five dominant microhabitats were recognized and sampled (with a share of at least $5 \%$ coverage): cobbles (microlithal) (M1), mixture of pebbles and sand (akal) (M2), mosses on macrolithal (M3), mosses on technolithal (M4) and mosses on mesolithal (cobbles) (M5). Inorganic substrate categories were defined using the Wentworth scale (Wentworth 1922).

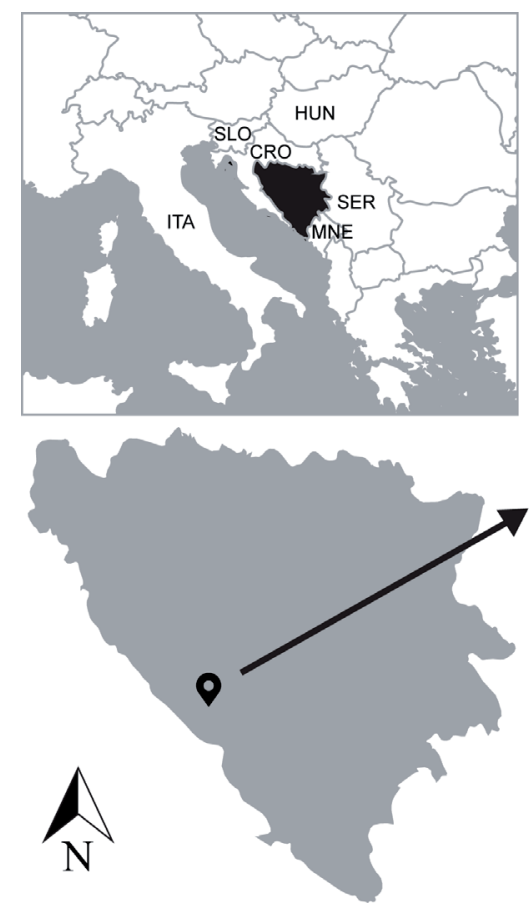

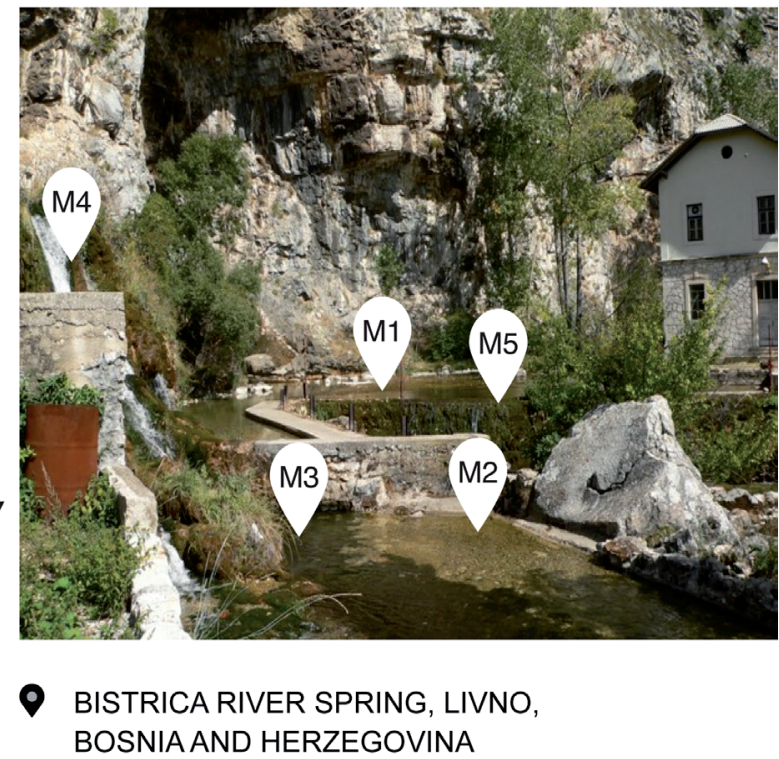

M1-M5 - Microhabitats
Figure 1. Geographical position of the Bistrica River Spring, located in Livno, Bosnia and Herzegovina, with sampled microhabitats. Legend: M1: cobbles (microlithal), M2: mixture of pebbles and sand (akal), M3: mosses on macrolithal, M4: mosses on technolithal, M5: mosses on mesolithal (cobbles). 
Samples were collected using Surber samplers (mesh size: $0.5 \mathrm{~mm}$; surface area $14 \mathrm{~cm} \times 14 \mathrm{~cm}$ at microhabitat with mosses on technolithal (M4) (due to very high macroinvertebrate abundance) and $25 \mathrm{~cm} \times 25 \mathrm{~cm}$ at all other microhabitats). Samples were preserved in $80 \%$ ethanol. Abundance was expressed as individuals $\mathrm{m}^{-2}$ to allow comparison of different sized samples.

Mayflies were identified to the lowest possible taxonomical level (depending on the nymphal stage; i.e., very small individuals of the Baetis genus were identified only to the genus level) using Müller-Liebenau (1969), Jacob (1974) and Bauernfeind and Humpesch (2001). After identification, total nymphal body length without cerci and antennae was measured using the micrometre on a dissecting stereomicroscope (Stemi 2000-C, Carl-Zeiss). A total of 4436 mayfly nymphs were measured. All voucher specimens are deposited at the Department of Biology, Faculty of Science, University of Zagreb, Croatia.

\section{Abiotic parameters}

Measurement of abiotic parameters was determined by two important facts: the small size of the studied spring and the fact that the spring is a protected water area. Therefore, the study was conducted in an $8 \mathrm{~m}$ transect, always at the same spot in the spring. Additionally, during each sampling event (monthly), all parameters were measured at the same time of day. Preliminary study indicated that physicochemical parameters, except water depth and water velocity, did not differ along the transect. Hence, at each sampling event, the following physicochemical water properties were measured (Table 1): water temperature, oxygen concentration, oxygen saturation (using the oximeter WTW Oxi 330/SET), $\mathrm{pH}$ (using the $\mathrm{pH}$-meter WTW $\mathrm{pH} 330$ ), conductivity (with the conductivity meter WTW LF 330), alkalinity (by titration with $0.1 \mathrm{M} \mathrm{HCl}$ ) and nutrients (ammonium by HRN ISO 70-3:1998 method, nitrates by HRN ISO 7890-3:2001 method and orthophosphates by HRN ISO 6878:2001 method). Additionally, at each microhabitat, water velocity (with P-670-M velocimeter; Dostmann electronic) and water depth (with handheld meter) were measured.

\section{Data analysis}

One-way ANOVA test with the Tukey HSD post hoc test was used to identify differences in water velocity and depth between microhabitats.

Hierarchical cluster analysis (HCA - UPGMA) and nonmetric multidimensional scaling (NMDS) ordination based on a Bray-Curtis similarity matrix were used to examine variability in mayfly assemblage composition among microhabitats. Prior to analysis, data were log transformed.

The composition of mayfly assemblages in terms of trophic structure and longitudinal zonal associations of species at various microhabitats was analysed using the classification given by Moog and Hartmann (2017), combined with Bauernfeind and Soldán (2012).
The non-parametric Kruskal-Wallis $\mathrm{H}$ test, followed by the multiple-comparison post hoc test, was used to determine differences among microhabitats in species richness, total abundance and the abundance of individual mayfly species.

Spearman's rank correlation coefficient was used to assess the correlation of species richness, total abundance and the abundance of individual species with water velocity and water depth.

Mayfly life cycles were analysed by grouping the nymphs into $1 \mathrm{~mm}$ body size classes and observing dark wing pads for mature nymphs.

Bray-Curtis similarity index, HCA and NMDS analyses were conducted in Primer 6 (Clarke and Gorley 2006). Oneway ANOVA, Kruskal-Wallis H test and Spearman's rank correlation coefficient were calculated in Statistica 13.0 (Dell Inc. 2016). All figures were processed with Adobe Illustrator CS6.

\section{Results}

\section{Abiotic parameters}

Most physicochemical water properties showed relatively small oscillations during the study period (Table 1). Ammonia values were elevated between February and July compared to the rest of the study period.

Water velocity (one-way ANOVA; $\mathrm{F}=30.15, \mathrm{df}=4.56$, $\mathrm{p}<0.001)$ and water depth $(\mathrm{F}=25.27, \mathrm{df}=4.56, \mathrm{p}<0.001)$ differed among microhabitats in the spring.

Microhabitats with mosses had higher water velocity compared to the microhabitat with cobbles (microlithal; M1) (Tukey HSD post hoc test; mosses on macrolithal (M3; p < 0.01 ), mosses on technolithal (M4; $p<0.001)$, mosses on mesolithal (cobbles) (M5; p $<0.001)$ ), and compared to the microhabitat with a mixture of pebbles and sand (akal; M2) (Tukey HSD post hoc test; mosses on macrolithal (M3; p < 0.001), mosses on technolithal (M4; $\mathrm{p}<0.001$ ), mosses on mesolithal (cobbles) (M5; $\mathrm{p}<0.001)$ ). Among microhabitats with mosses, velocity was higher on mosses on technolithal (M4) compared to mosses on macrolithal (M3; p < 0.01). Overall, mosses on technolithal (M4) had the highest water velocity, while the mixture of pebbles and sand (akal; M2) had the lowest velocity (Fig. 2a).

Depth was greater at the cobbles (microlithal; M1) microhabitat compared to other microhabitats (Tukey HSD post hoc tests; mosses on mesolithal (cobbles) (M5; p < 0.001), mosses on macrolithal (M3; $<<0.01)$, mosses on technolithal (M4; $\mathrm{p}<0.05$ ) and mixture of pebbles and sand (akal; M2; $\mathrm{p}<0.05)$ ). Furthermore, mosses on mesolithal (cobbles; M5) had lesser depth compared to mosses on macrolithal (M3; $\mathrm{p}<$ $0.001)$, mosses on technolithal $(\mathrm{M} 4 ; \mathrm{p}<0.001)$ and a mixture of pebbles and sand (akal) (M2; $<<0.001)$. Overall, the microhabitat with a mixture of pebbles and sand (akal; M2) had the greatest depth, while mosses on mesolithal (cobbles; M5) were the shallowest (Fig. 2b). 
Table 1. Mean values of physical and chemical water properties at the Bistrica River Spring measured from September 2007 to August 2008.

\begin{tabular}{|c|c|c|c|c|c|c|c|c|c|c|c|c|}
\hline $\begin{array}{l}\text { Abiotic factor / study } \\
\text { period }\end{array}$ & IX 07 & X 07 & XI 07 & XII 07 & I 08 & II 08 & III 08 & IV 08 & V 08 & VI 08 & VII 08 & VIII 08 \\
\hline Water temperature $\left({ }^{\circ} \mathrm{C}\right)$ & 8.8 & 8.3 & 7.9 & 8.0 & 8.0 & 8.1 & 8.0 & 8.1 & 9.0 & 8.2 & 8.0 & 8.4 \\
\hline $\mathrm{O}_{2}\left(\mathrm{mg} \mathrm{L}^{-1}\right)$ & 12.11 & 12.45 & 11.18 & 11.24 & 10.98 & 13.45 & 11.22 & 12.57 & 12.30 & 11.48 & 13.24 & 10.70 \\
\hline $\mathrm{O}_{2}(\%)$ & 107.6 & 110.7 & 97.2 & 98.0 & 114.0 & 139.2 & 100.5 & 109.9 & 105.7 & 100.6 & 119.6 & 94.2 \\
\hline $\mathrm{pH}$ & 8.23 & 7.57 & 7.86 & 7.36 & 8.21 & 8.09 & 8.19 & 8.34 & 7.00 & 7.85 & 8.62 & 8.53 \\
\hline Conductivity $\left(\mu \mathrm{S} \mathrm{cm}^{-1}\right)$ & 368 & 342 & 337 & 365 & 357 & 355 & 357 & 327 & 358 & 360 & 369 & 380 \\
\hline Alkalinity $\left(\mathrm{CaCO}_{3} \mathrm{mg} \mathrm{L}^{-1}\right)$ & 205.2 & 195.2 & 180.2 & 185.2 & 175.2 & 180.2 & 175.2 & 185.2 & 155.1 & 160.1 & 195.2 & 175.2 \\
\hline Nitrates $\left(\mathrm{mg} \mathrm{L}^{-1}\right)$ & 0.15 & 0.42 & 0.48 & 0.60 & 0.60 & 0.42 & 0.59 & 0.37 & 0.61 & 0.61 & 0.13 & 0.36 \\
\hline Ammonium (mg L $\left.{ }^{-1}\right)$ & 0.005 & 0.005 & 0.005 & 0.005 & 0.005 & 0.020 & 0.015 & 0.020 & 0.017 & 0.017 & 0.005 & 0.012 \\
\hline Phosphates (mg L $\left.{ }^{-1}\right)$ & 0.005 & 0.005 & 0.005 & 0.005 & 0.005 & 0.005 & 0.005 & 0.005 & 0.005 & 0.005 & 0.005 & 0.005 \\
\hline Water velocity $\left(\mathrm{cm} \mathrm{s}^{-1}\right)$ & 26.2 & 44.6 & 21.4 & 36.4 & 54.8 & 41.0 & 39.4 & 37.6 & 49.4 & 39.4 & 24.4 & 33.0 \\
\hline Water depth (cm) & 16.6 & 23.8 & 18.0 & 14.2 & 19.8 & 23.4 & 21.2 & 19.8 & 20.5 & 22.6 & 21.8 & 16.8 \\
\hline
\end{tabular}

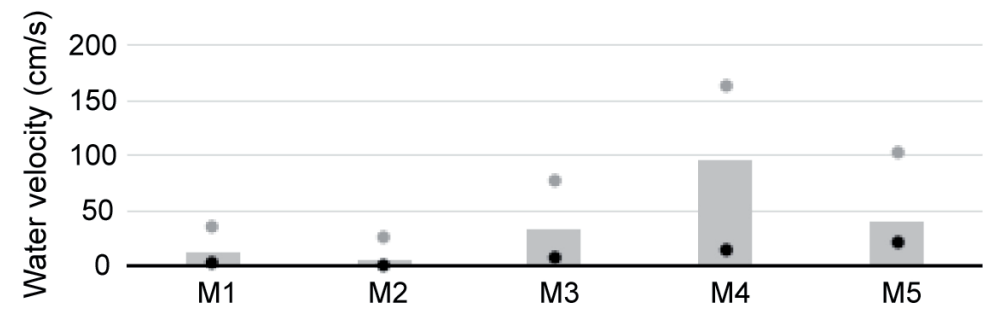

a)

Mean water velocity $\bullet$ Min $\bullet$ Max

Microhabitat

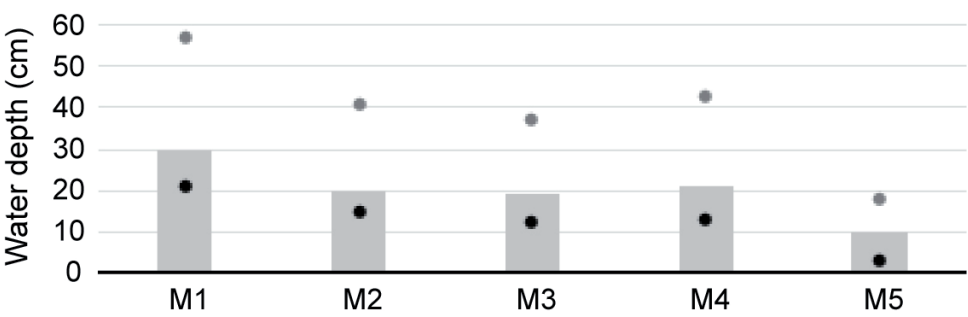

b) Mean water depth $\bullet$ Min $\bullet$ Max

Microhabitat
Figure 2. Mean, minimum and maximum values of a) water velocity and b) water depth at different microhabitats in the Bistrica River Spring measured from September 2007 to August 2008. Legend: M1: cobbles (microlithal), M2: mixture of pebbles and sand (akal), M3: mosses on macrolithal, M4: mosses on technolithal, M5: mosses on mesolithal (cobbles).
Mayfly assemblages

We collected and identified a total of 4436 mayfly nymphs belonging to three species: Baetis alpinus (Pictet, 1843), Baetis rhodani (Pictet, 1843) and Rhithrogena braaschi (Jacob, 1974).

NMDS ordination (Fig. 3) showed that mayfly assemblages did not group according to microhabitat type. Species richness and abundance were comparable among microhabitats (Kruskal-Wallis $\mathrm{H}$ test, multiple comparisons post hoc test, $\mathrm{H}(2, \mathrm{~N}=36)=3.89, \mathrm{p}>0.05)$. Both Baetis species were recorded at all microhabitats, while $R h$. braaschi was recorded at all microhabitats with the exception of mosses on the technolithal (M4) (Table 2). Species richness correlated negatively with water velocity (Spearman's rank correlation, $\mathrm{R}=-0.29, \mathrm{p}<0.05)$.

All microhabitats were characterized by the highest share of rhithral elements (species preferring upper and middle reaches), while potamal elements (species preferring lower reaches) were the least represented (Fig. 4a). Compared to microhabitats with mosses, microhabitats with inorganic substrates (cobbles, mixture of pebbles and sand) had a slightly higher percentage of crenal elements (spring loving species). Only grazers/scrapers and gatherers/collectors were present 
Table 2. Abundance ( $\mathrm{N}$, individuals $\mathrm{m}^{-2}$ ) and share (\%) of mayfly taxa in various microhabitats in the Bistrica River Spring collected from September 2007 to August 2008. Legend: M1: cobbles (microlithal), M2: mixture of pebbles and sand (akal), M3: mosses on macrolithal, M4: mosses on technolithal, M5: mosses on mesolithal (cobbles); indet. - unidentified individuals due to very juvenile stage.

\begin{tabular}{|c|c|c|c|c|c|c|c|c|c|c|}
\hline Mayfly taxa / Microhabitat & M1 (N) & M1 \% & $\mathrm{M} 2(\mathrm{~N})$ & M2 \% & M3 (N) & M3 \% & $\begin{array}{l}\text { M4 } \\
(\mathrm{N})\end{array}$ & $\begin{array}{c}\text { M4 } \\
\%\end{array}$ & $\begin{array}{l}\text { M5 } \\
(\mathrm{N})\end{array}$ & M5 \% \\
\hline Baetis sp. indet. & 0.0 & 0.0 & 0.0 & 0.0 & 196.0 & 36.2 & 3336.3 & 43.0 & 1365.0 & 64.0 \\
\hline Baetis rhodani (Pictet, 1843) & 200.0 & 21.3 & 94.7 & 28.4 & 56.0 & 10.4 & 42.5 & 0.6 & 109.3 & 5.1 \\
\hline Baetis alpinus (Pictet, 1843) & 581.3 & 62.0 & 72.0 & 21.6 & 286.7 & 53.0 & 4381.8 & 56.5 & 654.8 & 30.7 \\
\hline Rhithrogena braaschi (Jacob, 1974) & 156.0 & 16.6 & 166.7 & 50.0 & 2.7 & 0.5 & 0.0 & 0.0 & 2.7 & 0.1 \\
\hline$\Sigma$ & 937.3 & & 333.3 & & 541.3 & & 7760.5 & & 2131.8 & \\
\hline
\end{tabular}
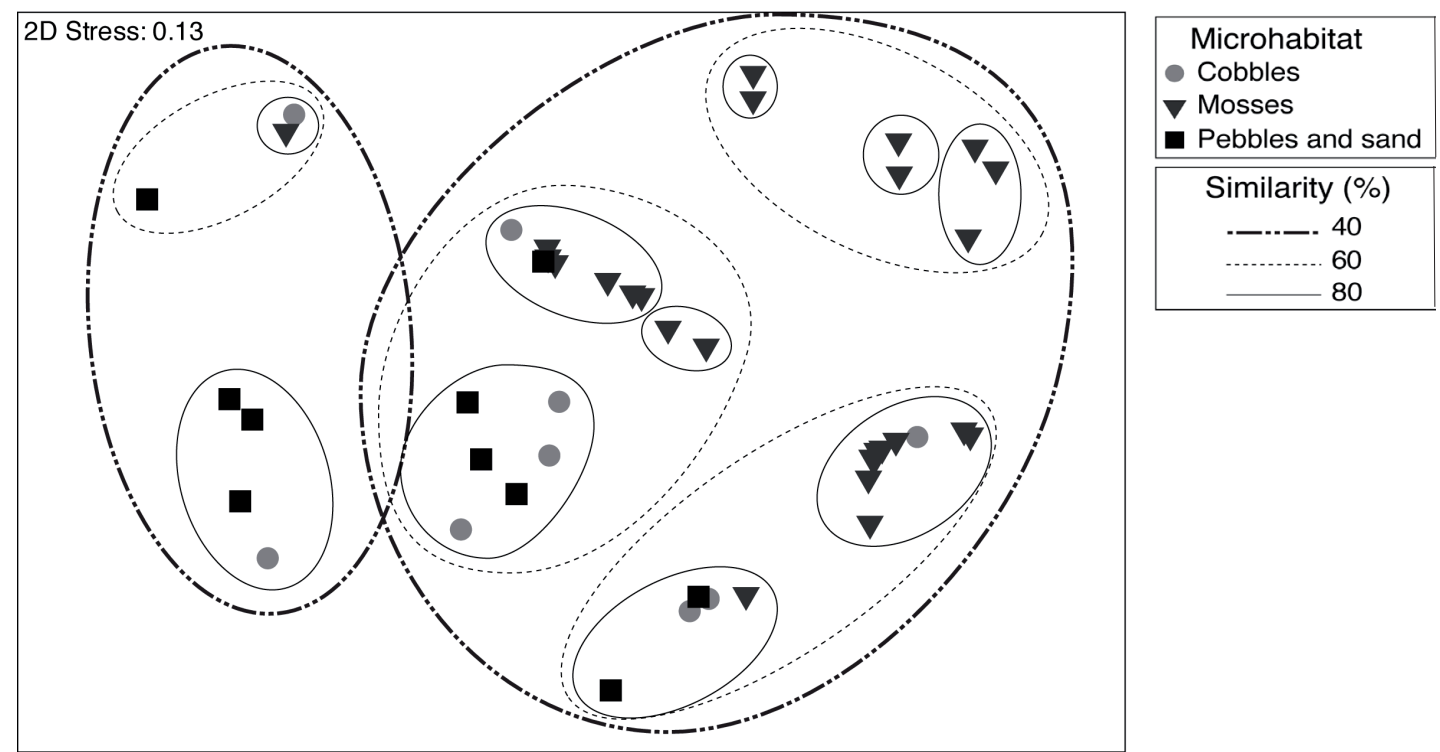

Figure 3. Non-metric multidimensional scaling (NMDS) ordination of mayfly assemblages based on the Bray-Curtis similarity coefficient (clusters obtained by group average linking, UPGMA) and their log-transformed abundances based on monthly samples taken from various microhabitats in the Bistrica River Spring.

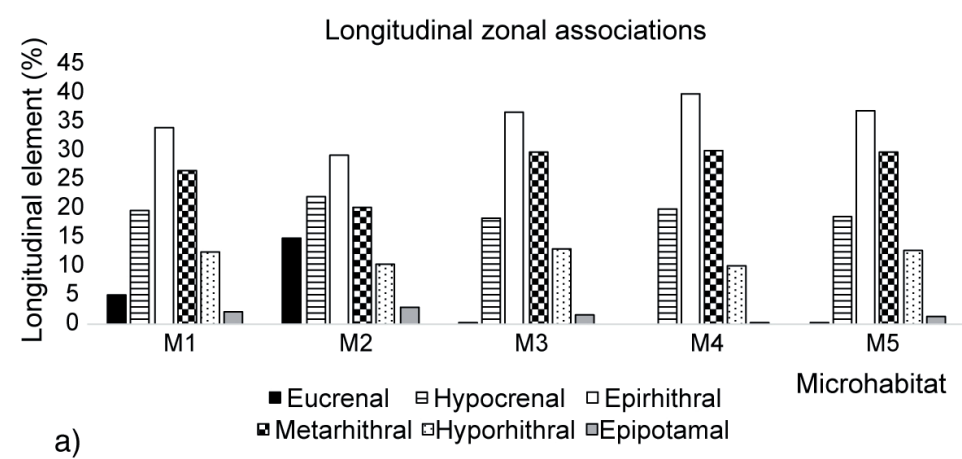

Figure 4. a) Mayfly assemblage structure according to longitudinal zonal associations, and b) trophic structure of mayfly species recorded at five microhabitats in the Bistrica River Spring. Microhabitats: M1: cobbles (microlithal), M2: mixture of pebbles and sand (akal), M3: mosses on macrolithal, M4: mosses on technolithal, M5: mosses on mesolithal (cobbles).

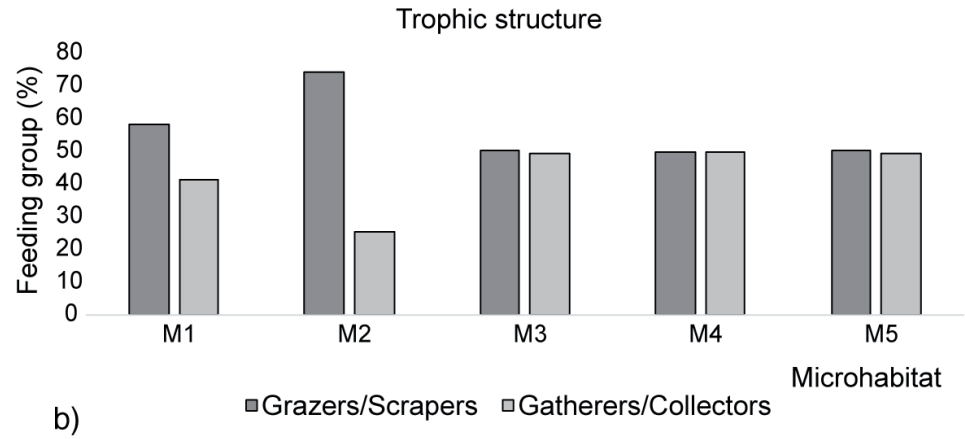


in the spring and were evenly represented at microhabitats with mosses, while microhabitats with inorganic substrates had a higher percentage of grazers/scrapers (Fig. 4b).

\section{Mayfly microhabitat selection}

Baetis alpinus was more abundant in mosses compared to mixture of pebbles and sand (Kruskal-Wallis $\mathrm{H}$ test, multiple comparisons post hoc test, $\mathrm{H}(2, \mathrm{~N}=36)=7.53, \mathrm{p}<0.05)$, while abundances of $B$. rhodani were comparable among microhabitats $(\mathrm{H}(2, \mathrm{~N}=36)=0.73, \mathrm{p}>0.05)$ (Table 2). Differences in the abundance of Rhithrogena braaschi were significant among microhabitats $(\mathrm{H}(2, \mathrm{~N}=36)=6.54, \mathrm{p}<$ $0.05)$, though the Multiple comparisons post hoc test could not determine which groups differed. Yet, the abundances were markedly higher in microhabitats with inorganic substrates (cobbles, mixture of pebbles and sand) compared to microhabitats with mosses (Table 2).

The abundance of Baetis alpinus positively correlated (Spearman correlation coefficient, $\rho=0.33, \mathrm{p}<0.05$ ) with water velocity, while abundances of $B$. rhodani $(\rho=-0.28$, p
$<0.05)$ and $R h$. braaschi correlated negatively $(\rho=-0.42$, p $<0.05)$. Moreover, abundance of $R h$. braaschi positively correlated with water depth $(\rho=0.25, p<0.05)$.

\section{Mayfly life cycles}

Baetis alpinus was recorded during the entire study period. The highest number of individuals was recorded between September 2007 and January 2008, when the highest number of juvenile nymphs with body length up to $3 \mathrm{~mm}$ was also collected. Mature nymphs (with dark wing pads) with body length between 7 and $10 \mathrm{~mm}$ were collected in September and October 2007 and between February and August 2008 (Fig. 5a).

Baetis rhodani was collected between September 2007 and January 2008, in March 2008 and between June and August 2008, when both juvenile and mature nymphs (with dark wing pads) were recorded (Fig. 5b).

Rhithrogena braaschi was recorded during the majority of the study period, with the highest number of both juvenile and mature nymphs (with dark wing pads) collected in

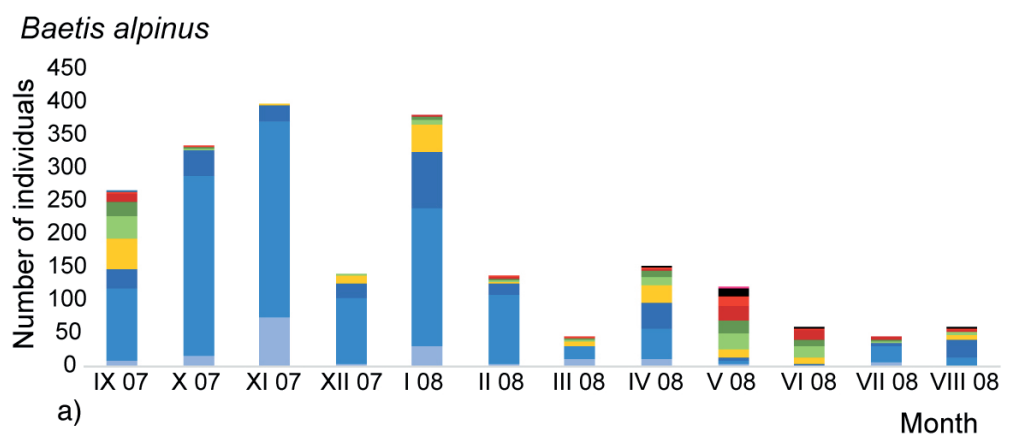

\section{Baetis rhodani}

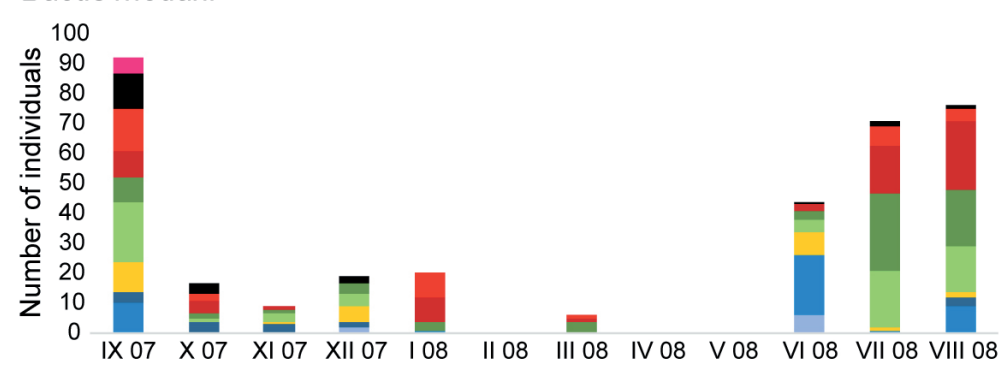

b)

Month

Rhithrogena braaschi

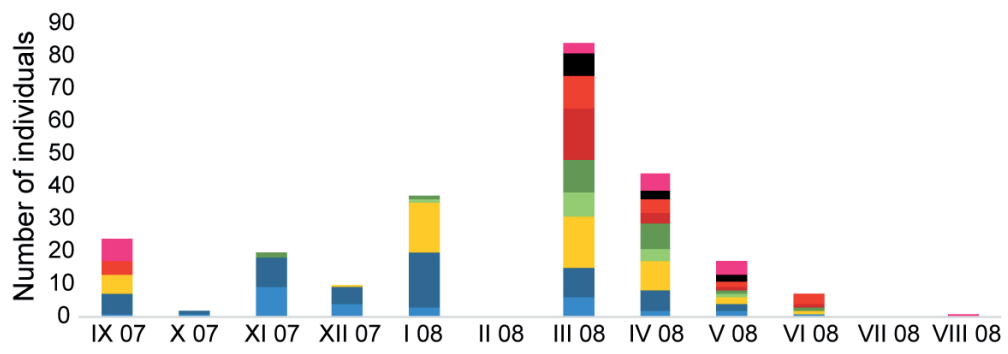

Figure 5. Seasonal dynamics of a) Baetis alpinus, b) Baetis rhodani and c) Rhithrogena braaschi at the Bistrica River Spring from September 2007 to August 2008. Body size classes: $\mathrm{A}=$ 0.01-0.99 mm; B = 1.00-1.99 mm; C $=2.00-2.99 \mathrm{~mm} ; \mathrm{D}=3.00-3.99 \mathrm{~mm} ; \mathrm{E}$ $=4.00-4.99 \mathrm{~mm} ; \mathrm{F}=5.00-5.99 \mathrm{~mm} ; \mathrm{G}$ $=6.00-6.99 \mathrm{~mm} ; \mathrm{H}=7.00-7.99 \mathrm{~mm}$; c) $\square=B \square C \square D \square E \square F \square G \square H \square I \square J$

Month $\mathrm{I}=8.00-8.99 \mathrm{~mm} ; \mathrm{J}=9.00-9.99 \mathrm{~mm}$. 
Figure 6. Abundances of different nymph size classes at microhabitats of the Bistrica River Spring from September 2007 to August 2008 for a) Baetis alpinus, b) Baetis rhodani and c) Rhithrogena braaschi. Body size classes: A $=0.01-0.99 \mathrm{~mm}$; $=1.00$ $1.99 \mathrm{~mm} ; \mathrm{C}=2.00-2.99 \mathrm{~mm} ; \mathrm{D}=$ $3.00-3.99 \mathrm{~mm} ; \mathrm{E}=4.00-4.99 \mathrm{~mm} ; \mathrm{F}$ $=5.00-5.99 \mathrm{~mm} ; \mathrm{G}=6.00-6.99 \mathrm{~mm}$; $\mathrm{H}=7.00-7.99 \mathrm{~mm} ; \mathrm{I}=8.00-8.99 \mathrm{~mm}$; $\mathrm{J}=9.00-9.99 \mathrm{~mm}$.

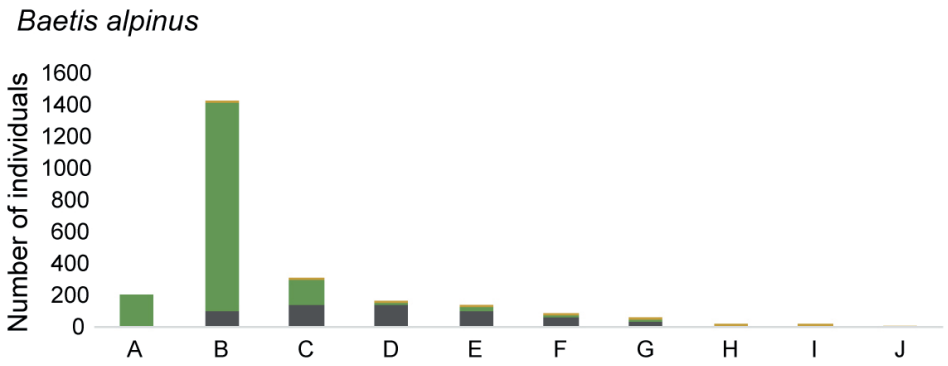

a)

Baetis rhodani

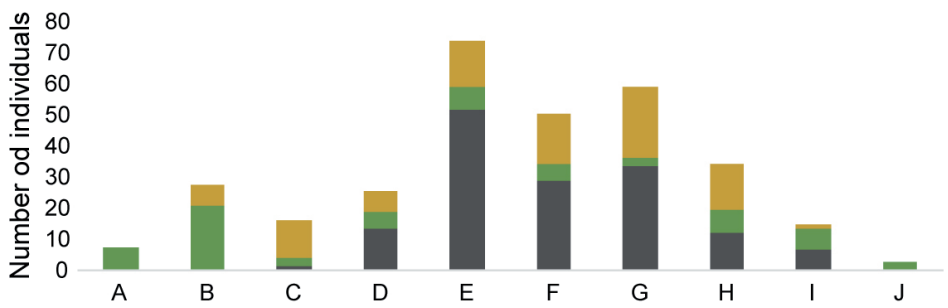

b)

Body size class

Rhithrogena braaschi

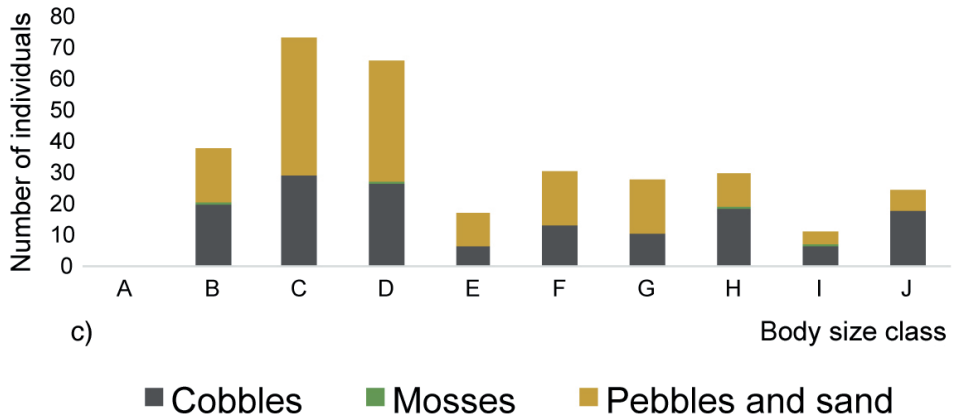

March 2008. Juvenile nymphs with body length up to $4 \mathrm{~mm}$ were present in most samples except in August 2008. Mature nymphs with body length between 8 and $10 \mathrm{~mm}$ were collected during spring and summer, i.e., in September 2007 and between March and August 2008 (Fig. 5c).

\section{Microhabitat selection during the life cycle}

Juvenile nymphs (with body length of 1 and $2 \mathrm{~mm}$ ) of Baetis alpinus were most numerous at microhabitats with mosses. Middle size nymphs (with body length between 3 and $6 \mathrm{~mm}$ ) were most numerous at the microhabitat with cobbles, while the abundances of mature nymphs (with body length between 8 and $10 \mathrm{~mm}$ ) were comparable between microhabitats on mosses and mixture of pebbles and sand (Fig. 6a).

Juvenile nymphs of Baetis rhodani were also most numerous at microhabitats with mosses. Middle sized and mature nymphs (with body length between 3 and $7 \mathrm{~mm}$ ) were most numerous at the microhabitat with cobbles. The microhabitat with a mixture of pebbles and sand had comparable abundances of nymphs belonging to all size classes. The smallest (body length up to $1 \mathrm{~mm}$ ) and largest (body length between 9 and $10 \mathrm{~mm}$ ) individuals were recorded only at microhabitats with mosses (Fig. 6b).

Juvenile and middle-sized nymphs (with body length up to $8 \mathrm{~mm}$ ) of Rhithrogena braaschi were most abundant at the microhabitat with a mixture of pebbles and sand. Mature nymphs (body length between 8 and $10 \mathrm{~mm}$ ) were mostly recorded from cobbles. Mosses had similar numbers of juvenile and mature nymphs, yet these abundances were very low (Fig. 6c).

\section{Discussion}

\section{Mayfly assemblages}

With only three recorded species, this study confirmed low species richness of mayfly assemblages in spring habitats (e.g., Bauernfeind and Moog 2000, Bottová and Derka 2013, Vilenica et al. 2014, 2016a, 2017a). Two of these species, Baetis alpinus and B. rhodani, are widely distributed in Europe, while the studied spring also contains Rhithrogena braaschi, which is restricted to the Balkan Peninsula 
(Bauernfeind and Soldán 2012). This is also the first record of this species for the fauna of Bosnia and Herzegovina (Bauernfeind and Soldán 2012, Savić et al. 2016). Such low diversity could be a result of the specific environmental factors, such as oligotrophic water quality, high alkalinity, and low and constant water temperature year round (Moog and Hartmann 2017, Harper and Peckarsky 2006, Vilenica et al. 2017a, b). Therefore, the domination of the cold stenotherm B. alpinus is not surprising (Buffagni et al. 2017). Baetis rhodani is an eurytherm species, while the temperature preferences of Rh. braaschi have not yet been systematically studied. However, the species has previously been recorded at similar habitats (Vilenica et al. 2016ab, 2017ab, Buffagni et al. 2017), indicating its preferences for colder water conditions. A high share of rhithral elements in the mayfly assemblage structure is due to the presence of spring and upper reaches loving species, B. alpinus and Rh. braaschi (Bauernfeind and Soldán 2012, Vilenica et al. 2016 a, b, 2017a, b, Buffagni et al. 2017). The presence of the potamal element is due to the eurytopic $B$. rhodani that inhabits a wide range of freshwater habitats (Bauernfeind and Soldán 2012, Buffagni et al. 2017). Similar composition and structure of mayfly assemblages was recorded in several springs of the Dinaric Karst in neighbouring Croatia (Vilenica et al. 2014, 2016ab, 2017ab). Moreover, such an assemblage structure is in partial agreement with some other studies conducted in European springs [e.g., Mori and Brancelj 2006 (with records of Baetis melanonyx (Pictet, 1843), B. rhodani, Ecdyonurus picteti (Meyer-Dür, 1864), Ecdyonurus zelleri Eaton, 1885, Rhithrogena gr. semicolorata), Maiolini et al. 2011 (with records of B. alpinus, B. rhodani, Ecdyonurus gr. helveticus, Rhithrogena gr. hybrida, Rh. gr. loyolaea and Serratella ignita (Poda, 1971), Bottová and Derka 2013 (with records of B. alpinus, B. rhodani and Rhithrogena semicolorata (Curtis, 1834)]. However, the results differ markedly from some other studies [e.g., Barquín and Death 2009 (with records of Baetis spp., Ecdyonurus spp., Rhithrogena spp. and S. ignita), Savić et al. 2016 (with records of B. rhodani, Ecdyonurus sp., Electrogena sp., Habroleptoides confusa Sartori \& Jacob, 1986, Ephemera danica Müller, 1764 and Caenis sp.)].

High mayfly abundance in the studied spring could be a consequence of anthropogenic impact, i.e., inflow of organic matter into the habitat, which could have enhanced periphyton development providing more food resources for mayfly nymphs. Firstly, the spring is closely surrounded by several houses. Moreover, it is also connected with Blidinje Lake, an anthropogenic reservoir (Radoš 2017) relatively rich in nutrients and organic matter (Ivanković et al. 2011), and its waters drain into the spring. Such high mayfly abundance was also recorded in the anthropogenically impacted Ruda Spring in neighbouring Croatia (Vilenica et al. 2016a), while unimpacted karst springs in the same area had markedly lower abundances (Vilenica et al. 2016a, 2017a).

\section{Microhabitat selection}

Freshwater microhabitats are characterized by the combination of substrate type, water velocity, water depth, or- ganic matter deposits, turbulence and hydraulic parameters (Lampert and Sommer 1997, Gordon et al. 2002, Miliša et al. 2006). Mayfly nymphs use a wide range of microhabitats to search for food resources and for their activities (resting, movement, refuge from predators). Habitat specialists depend on certain microhabitats during essential parts of their nymphal stages, e.g., stable substrates for filter-feeders or lithal with epilithic diatoms for grazers (Moog and Hartmann 2017, Schmidt-Kloiber and Hering 2015). The Bistrica River Spring has an open canopy that enables the growth of algae and macrophytes, important food resources for the nymphs. Therefore, similar shares of grazers/scrapers and gatherers/ collectors within the assemblages were not surprising. All species were recorded at all available microhabitats, though each species showed a certain level of microhabitat preference. Buffagni et al. (2017) found that feeding strategies and food availability are closely related to microhabitat selection. Moreover, although all three of the recorded species are rheophilic, they were confined to microhabitats with different water velocity, likely in relation to food availability. Rhithrogena braaschi is a grazer/scraper that feeds on periphyton overgrowth on stony substrates (Bauernfeind and Soldán 2012, Buffagni et al. 2017), which is why it was most numerous at inorganic substrates characterized with lower water velocity and higher water depth compared to microhabitats with mosses. Both Baetis species can feed by grazing/scraping or gathering/collecting using both inorganic substrates overgrown by periphyton and mosses with trapped organic matter as food resources (Bouchard 2004, Buffagni et al. 2017). Thus, B. alpinus was mainly collected from microhabitats with mosses associated with the highest water velocity that brings the required quantities of organic matter into the microhabitat (Ciborowski 1983). These results only partially corroborate previous studies where the species was recorded at microhabitats with megalithal and macrolithal (Buffagni et al. 2017). Our results could be related to interspecific competition with the other two species at microhabitats with lithal substrates. The eurytopic $B$. rhodani inhabits a wide range of microhabitats (Buffagni et al. 2017), which was also the case in our study. Yet, as the species was associated with moderate water velocity, it was somewhat more numerous at microhabitat with cobbles.

In habitats with stable environmental conditions, such as springs, competition (McAuliffe 1984, Feminella and Resh 1990) and predation (Flecker and Allan 1984, Teague et al. 1985) can play an important role in the population dynamics of aquatic macroinvertebrates. The movements of nymphs among the available microhabitats during different stages of their growth was also recorded. Juvenile nymphs of the two Baetis species were most numerous at microhabitats with mosses, where they could find large quantities of organic matter to feed on and refuge from predators (e.g., Marshall and Westlake 1990, Schulz et al. 2003, Miliša et al. 2006). On the other hand, larger and mature nymphs also visited inorganic substrates where they could find additional food resources in the periphyton. Juvenile and mid-sized nymphs of $R h$. braaschi were more numerous at inorganic microhabitats with smaller particle size (i.e., mixture of pebbles and sand), 
while mature nymphs used larger inorganic particles, likely to graze on. This shift in microhabitat selection could be a result of intraspecific competition (Hart 1983). Water velocity also has an important influence on the distribution of nymphs related to size, i.e., older nymphs were recorded to relocate at microhabitats with higher velocity or to gather in shoals near river banks (Kovalek 1978). In our study, all microhabitats had a relatively fast water current and were relatively shallow, and more mature nymphs shifted from microhabitats with higher to lower water velocity. Only B. alpinus remained at microhabitats with the highest velocities during the entire life cycle, as their nymphs can tolerate a strong water current (up to $1.5 \mathrm{~ms}^{-1}$ ) (Bauernfeind and Soldán 2012). Together with competition for food resources (Buffagni et al. 1995), movements of mayfly nymphs among microhabitats could also be a result of seeking an appropriate emergence spot (Elliott and Humpesch 1983, Wagner et al. 2011).

\section{Life cycles}

The life cycle of B. alpinus has been determined as variable (univoltine or bivoltine) depending on the environmental conditions and altitude (Sowa 1975, Clifford 1982, Kukuła 1997, López-Rodríguez et al. 2008). Due to lower water temperatures, previous studies reported a univoltine life cycle at higher (upstream) sites, while at lower (downstream) sites, the life cycle was bivoltine (e.g., Landa 1969, Kukuła 1997). In the Bistrica River Spring, the species had a bivoltine life cycle, which corroborates the study of Bottová and Derka (2013) conducted in a karst spring in Slovakia. Due to stable thermal conditions, the life cycle of $B$. rhodani, a species with a flexible life cycle (Clifford 1982, Bauernfeind and Humpesch 2001), was determined as polyvoltine, as the most commonly reported type of life cycle (e.g., Buffagni et al. 2002, Erba et al. 2003). Yet, our results are not in accordance with Bottová and Derka (2013) who determined its life cycle as univoltine. The biology and ecology of Rh. braaschi is still insufficiently investigated, though its life cycle is considered to be univoltine with a short emergence period in spring and early summer (Bauernfeind and Soldán 2012). In the Bistrica River Spring, the life cycle was univoltine, though the emergence period was prolonged due to the stable thermal conditions, corroborating the study of Vilenica et al. (2017b) in karst lotic habitats in Croatia.

\section{Conclusions}

With a newly recorded species for Bosnia and Herzegovina, Rhithrogena braaschi, this study contributes to our knowledge of the insufficiently investigated mayfly fauna of the Balkan Peninsula. Due to specific environmental conditions, especially low and constant water temperatures, mayfly assemblages in karst springs could be characterized as species poor (e.g., Vilenica et al. 2016a, 2017a). The Dinaric Karst habitats have long been recognized as a global biodiversity hotspot (Bãnãrescu 2004, Ivković and Plant 2015). Yet, at the same time they are strongly threatened by numerous anthropogenic pressures (Freyhof 2012, Schwarz 2012).
Since mayflies are widely used as bio-indicators of freshwater ecosystems (Landa and Soldán 1991), new insights into mayfly ecology, i.e., their microhabitat preferences and life histories, could contribute to the classification and protection of karst freshwater habitats in the Balkan Peninsula and form an important basis for further research and conservation practices for European mayflies and their habitats.

Acknowledgements: The authors would like to thank Assist. Prof. A. Delić, Dr. I. Stanković, Dr. M. Pavlek and family Rimac for their indispensable assistance during the field investigations. Many thanks are due to Mag. I. Krulik and M. Jelenčić for help with sorting the collected material, and to M. Katar for help with the artwork. Finally, we would like to thank the reviewers for their useful suggestions that markedly improved the manuscript.

\section{References}

Bãnãrescu, P.M. 2004. Distribution pattern of the aquatic fauna of the Balkan Peninsula. In: H. Griffith, B. Kryštufek and J. M. Reed (eds.), Balkan Biodiversity Pattern and Process in the European Hotspot. Kluwer Academic Publishers, Dordrecht. pp. 203-219.

Barquín, J. and M. Scarsbrook. 2008. Management and conservation strategies for cold-water springs. Aquat. Conserv. 18:580-591.

Barquín, J. and R. Death. 2009. Physical and chemical differences in karst springs of Cantabria, northern Spain: Do invertebrate communities correspond? Aquat. Ecol. 43:445-455.

Bauernfeind, E. and U.H. Humpesch. 2001. Die Eintagsfliegen Zentraleuropas - Bestimmung und Ökologie. Verlag NMW, Wien.

Bauernfeind, E. and O. Moog. 2000. Mayflies (Insecta: Ephemeroptera) and the assessment of ecological integrity: a methodological approach. Hydrobiologia 422:71-83.

Bauernfeind, E. and T. Soldán. 2012. The Mayflies of Europe (Ephemeroptera). Apollo Books, Ollerup, Denmark.

Bonacci, O. 2009. Karst landscape ecohydrology. In: Proceedings of International Symposium on Water Management and Hydraulic Engineering. Ohrid. pp. 781-790.

Bottová, K. and T. Derka. 2013. Life cycle and secondary production of mayflies and stoneflies in a karstic spring in the West Carpathians. Ann. Zool. Fenn. 50 (3):176-188.

Bouchard, R.W. Jr. 2004. Guide to Aquatic Macroinvertebrates of the Upper Midwest. Water Resources Center, University of Minnesota, St. Paul, Minnesota.

Brittain, J.E. 1991. Life history characteristics as a determinant of the response of mayflies and stoneflies to man-made environmental disturbance (Ephemeroptera and Plecoptera). In: J. AlbaTercedor and A. Sanchez-Ortega (eds.), Overview of Strategies of Ephemeroptera and Plecoptera. Sandhill Crane Press, Gainesville, U.S.A. pp. 539-545.

Buffagni, A., D.G. Armanini, M. Cazzola, J. Alba-Tercedor, M.J. López-Rodríguez, J. Murphy, L. Sandin and A. Schmidt-Kloiber. 2017. Dataset "Ephemeroptera". www.freshwaterecology.info the taxa and autecology database for freshwater organisms, version 7.0 (accessed on 10.01.2018).

Buffagni, A., G. Crosa and R. Marchetti.1995. Size-related shifts in the physical habitat of two mayfly species (Ephemeroptera). Freshwater Biol. 34:297-302. 
Buffagni, A., S. Erba and G. Origgi. 2002. Efemerotteri. 2. Cicli biologici e sviluppo larvale. In: Atlante della biodiversit 'a del Parco del Ticino, vol. 2, Monografie. Parco del Ticino, Corbetta. pp. $60-73$.

Cantonati, M. and K. Ortler. 1998. Using spring biota of pristine mountain areas for long term monitoring. Hydrology, Water Resources and Ecology in Headwaters (Proceedings of the Headwater ' 98 Conference held at Merano/Meran, Italy, April 1998). IAHS Publications 248:379-385.

Cantonati, M., R. Gerecke and E. Bertuzzi. 2006. Springs of the Alpssensitive ecosystems to environmental change: from biodiversity assessments to long-term studies. Hydrobiologia 562:59-96.

Ciborowski, J.J.H. 1983. Influence of current velocity, density, and detritus on drift of two mayfly species (Ephemeroptera). Can. J. Zool. 61:119-125.

Clarke, K.R. and R.N. Gorley. 2006. PRIMER V6: User Manual/ Tutorial. Primer-E, Plymouth.

Clifford, H.F. 1982. Life cycles of mayflies (Ephemeroptera) with special reference to voltinism. Quaest. Entomol. 18(1-4):15-90.

Dell Inc. 2016. Dell Statistica (data analysis software system). Version 13. software.dell.com.

Elliott, J.M. and U.H. Humpesch. 1983. A Key to the Adults of the British Ephemeroptera with Notes on their Ecology. Scientific Publications of the Freshwater Biological Association, No. 47 Ambleside, Cumbria

Elliott, J.M., U.H. Humpesch and T.T. Macan. 1988. Larvae of the British Ephemeroptera: A Key with Ecological Notes. Scientific Publications of the Freshwater Biological Association, No. 49, Ambleside, Cumbria.

Erba, S., L. Melissano and A. Buffagni. 2003. Life cycles of Baetidae (Insecta: Ephemeroptera) in a North Italian Prealpine stream. In: E. Gaino (ed.), Research Update on Ephemeroptera \& Plecoptera. Università di Perugia, Perugia. pp. 177-186.

Feminella J.W. and V.H. Resh. 1990. Hydrologic influences, disturbance, and intraspecific competition in a stream caddisfly population. Ecology 71:2083-2094.

Ferrington, L.C.J. 1995. Biodiversity of aquatic insects and other invertebrates in springs: introduction. J. Kansas Entomol. Soc. $68: 1-3$.

Ferro, M.L. and R.W. Sites. 2007. The Ephemeroptera, Plecoptera, and Trichoptera of Missouri State Parks, with notes on biomonitoring, mesohabitat associations, and distribution. J. Kansas Entomol. Soc. 80:105-129.

FHMZ BIH. 2013. Meteorološki godišnjak 2007. B\&H, Sarajevo.

Flecker, A.S. and J.D. Allan. 1984. The importance of predation, substrate and spatial refugia in determining lotic insect distributions. Oecologia 64:306-313.

Freyhof, J. 2012. Threatened freshwater fishes and molluscs of the Balkan, potential impact of hydropower projects. Unpublished report. ECA Watch Austria \& EuroNatur.

Gordon, N.B., T.A. McMahon and B.L. Finlayson. 1992. Stream Hydrology: An Introduction for Ecologists. Wiley, Chichester.

Harper, M.P. and B.L. Peckarsky. 2006. Emergence cues of a mayfly in a high-altitude stream ecosystem: potential response to climate change. Ecol. Appl. 16(2):612-621.

Hart, D.D. 1983. The importance of competitive interactions within stream populations and communities. In: J.R. Barnes and G.W. Minshall (eds.), Stream Ecology, Applications and Testing of General Ecological Theory. Plenum Press, New York. pp. 99136.

Ivanković, A., E.V. Habul and Z. Knezović. 2011. Physicochemical characteristics of shallow, high mountains Lake Blidinje (in a karst area of Bosnia and Herzegovina) with emphasis on its trophic status. Oceanol. Hydrobiol. St. 40(3):19-27.

Ivković, M. and A. Plant. 2015. Aquatic insects in the Dinarides: identifying hotspots of endemism and species richness shaped by geological and hydrological history using Empididae (Diptera). Insect Conserv. Diver. 1-9. DOI: http://dx.doi.org/10.1111/ icad. 12113.

Jacob, U. 1974. Rhithrogena braaschi n. sp., eine neue Heptageniidae aus Bulgarien (Insecta, Ephemeroptera). Ent. Nachr. 18(1112):167-173

Kløve, B., P. Ala-aho, G. Bertrand, Z. Boukalova, A. Ertürk, N Goldscheider, J. Ilmonen, N. Karakaya, H. Kupfersberger, J. Kvœrner, A. Lundberg, M. Mileusnić, A. Moszczynska, T. Muotka, E. Preda, P. Rossi, D. Siergieiev, J. Šimek, P. Wachniew, V. Angheluta and A. Widerlund. 2011. Groundwater dependent ecosystems. Part I: Hydroecological status and trends. Environ. Sci. Policy 14:770-781.

Kovalek, W.P. 1978. Relationships between size of stream insects and current velocity. Can. J. Zool. 56:178-186.

Kukuła, K. 1997. The life cycles of three species of Ephemeroptera in two streams in Poland. Hydrobiologia 353:193-198.

Lampert, W. and U. Sommer. 1997. Limnoecology: The Ecology of Lakes and Streams. Oxford University Press, Oxford

Landa, V. 1969. Jepice - Ephemeroptera. Fauna CSSR: 18 Academia, Prague.

Landa V. and T. Soldán. 1991. The possibility of mayfly faunistics to indicate environmental changes of large areas. In: J.A. Tercedor and J.S. Ortega (eds.), Overview and Strategies of Ephemeroptera and Plecoptera. Sandhill-Crane Press, Gainesville, Florida. pp. $559-565$.

Lenat, D.R. and D.L. Penrose. 1996. History of the EPT taxa richness metric. J. N. Am. Benthol. Soc. 13:305-306.

Likens, G.E. 2010. Biogeochemistry of Inland Waters. Elsevier Science, London.

López-Rodríguez, M.J., J.M. Tierno de Figueroa and J. AlbaTercedor. 2008. Life history and larval feeding of some species of Ephemeroptera and Plecoptera (Insecta) in the Sierra Nevada (Southern Iberian Peninsula). Hydrobiologia 610(1):277-295.

Magdalenić, A. 1971. Hidrogeologija sliva Cetine. Jugoslavenska akademija znanosti i umjetnosti (JAZU) 7(4):89-169.

Maiolini, B., M. Carolli and L. Silveri. 2011. Ephemeroptera, Plecoptera and Trichoptera in springs in Trentino (south-eastern Alps). J. Limnol. 70:122-133.

Malez, M. 1963. Prilog poznavanju speleoloških odnosa na Glamočkom i Duvanjskom polju. Krš Jugoslavije. Jugoslavenska akademija znanosti i umjetnosti 4:171-200

Marshall, E.J.P. and D.F. Westlake. 1990. Water velocities around water plants in chalk streams. Folia Geobot. Phytotx. 25:279-289.

McAuliffe, J.R. 1984. Competition for space, disturbance and the structure of a benthic stream community. Ecology 65:894-908.

Mihevc, A., N. Zupan-Hajna and M. Prelovšek. 2010. Case study from the Dinaric karst of Slovenia. In: A. Mihevc, M. Prelovšek and N. Zupan-Hajna (eds.), Introduction to the Dinaric Karst. Karst Research Institute, Postojna. pp. 49-66.

Miliša, M., I. Habdija, B. Primc-Habdija, I. Radanović and R. Matoničkin Kepčija. 2006. The role of flow velocity in the vertical distribution of particulate organic matter on moss-covered travertine barriers of the Plitvice Lakes (Croatia). Hydrobiologia 553:231-243.

Moog, O. and A. Hartmann. 2017. Fauna Aquatica Austriaca 3. BMLFUW, Wien. 
Mori N. and A. Brancelj. 2006. Macroinvertebrate communities of karst springs of two river catchments in the Southern Limestone Alps (the Julian Alps, NW Slovenia). Aquat. Ecol. 40:69-83.

Müller-Liebenau, I. 1969. Revision der europäischen Arten der Gattung Baetis Leach, 1815. (Insecta, Ephemeroptera). Gewasser und Abwasser 66/67:95-101.

Odum, H.T. 1957. Trophic structure and productivity of Silver Springs, Florida. Ecol. Monogr. 27:55-112.

Petrović, A., D. Milošević, M. Paunović, S. Simić, N. Đorđević, M. Stojković and V. Simić. 2015. New data on the distribution and ecology of the mayfly larvae (Insecta: Ephemeroptera) of Serbia (central part of the Balkan Peninsula). Turk. J. Zool. 39:195-209.

Previšić, A., J. Schnitzler, M. Kučinić, W. Graf, H. Ibrahimi, M. Kerovec and S.U. Pauls. 2014. Microscale vicariance and diversification of Western Balkan caddisflies linked to karstification. Freshw. Sci. 33:250-262.

Raddum, G.G. and A. Fjellheim.1993. Life cycle and production of Baetis rhodani in a regulated river in Western Norway: comparison of pre- and post-regulation conditions. Regul. Rivers: Res. Manage. 8:49-61.

Radoš, D. 2017. A history of the occurrence of Blidinje Lake (Bosnia and Herzegovina). Geoadria 22(1):1-40. DOI: 10.15291/geoadria.1334.

Savić, A., D. Dmitrović and V. Pešić. 2016. Ephemeroptera, Plecoptera, and Trichoptera assemblages of karst springs in relation to some environmental factors: a case study in central Bosnia and Herzegovina. Turk. J. Zool. 41:119-129.

Scarsbrook, M., J. Barquin and D.P. Gray. 2007. New Zealand Coldwater Springs and their Biodiversity. Science for Conservation 278, Department of Conservation, Wellington, New Zealand.

Schmidt-Kloiber, A. and D. Hering. 2015. www.freshwaterecology. info - An online tool that unifies, standardises and codifies more than 20,000 European freshwater organisms and their ecological preferences. Ecol. Indic. 53:271-282.

Schulz, M., H.-P. Kozerski, T. Pluntke and K. Rinke. 2003. The influence of macrophytes on sedimentation and nutrient retention in the lower River Spree (Germany). Water Res. 37:569-578.

Schwarz, U. 2012. Balkan Rivers-The Blue Heart of Europe, Hydromorphological Status and Dam Projects. Report, Vienna, Austria.
Smith, J., P. J. Wood and J. Gunn. 2003. The influence of habitat structure and flow permanence on invertebrate communities in karst springs systems. Hydrobiologia 510:53-66.

Sowa, R. 1975. Ecology and biogeography of mayflies (Ephemeroptera) of running waters in the Polish part of the Carpathians. 2. Life cycles. Acta Hydrobiol. 17:319-353.

Staudacher, K. and L. Füreder. 2007. Habitat complexity and invertebrates in selected Alpine springs (Schütt, Carinthia, Austria). Int. Rev. Hydrobiol. 92:465-479.

Teague, S.A., A.W. Knight and B.N. Teague. 1985. Stream microhabitat selectivity, resource partitioning, and niche shifts in grazing caddisfly larvae. Hydrobiologia 128:3-12.

Vilenica, M., J.-L. Gattolliat, M. Ivković, M. Kučinić, V. Mičetić Stanković, Z. Mihaljević and M. Sartori. 2014. The mayfly fauna (Insecta, Ephemeroptera) of the Plitvice Lakes National park, Croatia. Nat. Croat. 23(2):349-363.

Vilenica, M., A. Previšić, M. Kučinić, J.-L. Gattolliat, M. Sartori and Z. Mihaljević. 2016a. Distribution and autecology of mayflies (Insecta, Ephemeroptera) in a Mediterranean river in the Western Balkans. Entomol. News 126(1):19-35.

Vilenica, M., A. Previšić, M. Ivković, A. Popijač, I. Vučković, M. Kučinić, M. Kerovec, J.-L. Gattolliat, M. Sartori and Z. Mihaljević. 2016b. Mayfly (Insecta: Ephemeroptera) assemblages of a regulated perennial Mediterranean river system in the Western Balkans. Biologia 71(9):1038-1048.

Vilenica, M., V. Mičetić Stanković, M. Sartori, M. Kučinić and Z. Mihaljević. 2017a. Environmental factors affecting mayfly assemblages in tufa-depositing habitats of the Dinaric Karst. Knowl. Manag. Aquat. Ec. 418(14):1-12.

Vilenica, M., M. Ivković, M. Sartori and Z. Mihaljević. 2017b. Mayfly emergence along an oligotrophic Dinaric karst hydrosystem: spatial and temporal patterns, and species-environment relationship. Aquat. Ecol. 51:1-17.

Wagner, R., J. Marxsen, P. Zwick and E.J. Cox. 2011. Central European Stream Ecosystems: The Long Term Study of the Breitenbach. Wiley, New York.

Wentworth, C.K. 1922. A scale of grade and class terms for clastic sediments. J. Geol. 30(5):377-392.

Received February 4, 2018 Revised April 5, June 13, 2018

Accepted June 23, 2018 